DOI https://doi.org/10.36059/978-966-397-242-8-9

\author{
Федорова О. В., \\ кандидат філологічних наук, \\ доцент кафедри англійської мови з підготовки морських фахівців \\ за скороченою програмою \\ Херсонської державної морської академії, \\ м. Херсон
}

\title{
НАУКОВІ ПІДХОДИ ДО ДОСЛІДЖЕННЯ ХУДОЖНЬОГО ОБРАЗУ В СУЧАСНІЙ ЛІНГВІСТИЦІ
}

Анотація. Науковий доробок, присвячений вивченню художнього образу, включає досліжження його внутрішньої структури за такими компонентами, як зміст, ідея (чуттєвий образ) та зовнішня форма об'єктивації образу (О.О. Потебня); розкриття когерентної природи художнього образу як концентрованого втілення суті твору, що визначає взаємозв'язок та взаємодію всіх його елементів (В.В. Виноградов); встановлення засобів створення синкретичності художнього образу (Н.Д. Арутюнова), тобто здатності об'єднувати у собі інформацію про навколишній світ та відтворювати об'єкт у його цілісності; виявлення кумулятивної специфіки композиції художнього образу (В.А. Кухаренко) як узагальнюючого, збірного, побудованого на основі вторинних або образних номінацій. Однак у сучасній лінгвістиці немає чіткої дефініції художнього образу, а питання щодо його змісту та призначення саме у художньому прозовому мовленні не отримало належної уваги $і$ залишається відкритим. Окрім цього, поза увагою дослідників залишається прагматичний аспект художнього образу.

Актуальність досліжження визначається, по-перше, антропоцентричною спрямованістю сучасної лінгвістики, їі скерованістю на вивчення людини у різних їі іпостасях - зовнішньому та внутрішньому світі, що дозволяє говорити про те, які саме лінгвокогнітивні структури мислення забезпечують організацію інформації про художній образ. По-друге, загальною тенденцією до розгляду семантики художнього тексту крізь призму ментальних процесів, що дає відповідь на питання «як» $і$ «чому саме такими засобами» прямі й образні номінації об'єктивують знання людини про світ. 
у дослідженні «художній образ» розуміємо як кумулятивний, синтетичний, такий, що інкорпорує семантику образних та прямих номінації, розпорошених по художніх текстах, проте переважає їх суму за спільною смисловою значущістю. Останнє положення підкріплюється тим фактом, що перлокутивний компонент кожного непрямого акту художньої комунікації полягає не у передачі знань про певний соціальний тип людини (ілокутивний компонент), а в тому, щоб змінити уявлення читача щодо стилю життя, соціальних відношень й внутрішнього світу людини, яка знаходиться в межах певного соціального рангу.

Загальний зміст художнього образу породжується глобальною ментальною репрезентацією - базовим текстовим світом, за умови існування якого існує і сам художній образ. Текстовий світ спочатку окреслюється дейктичними, референційними елементами та операторами модальності, установленими в тексті, а вже потім розширюється завдяки знанням, структурованим схемами та фреймами.

\section{Вступ}

Філософські уявлення щодо образу як форми відображення об'єктивної дійсності у свідомості людини пов'язують з кінцем XVIII ст. 3 позиції концепції пізнання I. Канта, за образом стоїть єдність чуттєвого та розумового уявлення [1, с. 156]. Г. Гегель указує на чуттєву природу образу [2] і вважає художній образ рушійним механізмом живопису. I.P. Гальперін акцентує увагу на сприйнятті, визначаючи образ як таке використання мовних засобів, за якого можливим $€$ чуттєве сприйняття абстрактного поняття, викликаючи асоціації між загальним й частковим, абстрактним й конкретним, загальноприйнятим й фактичним [3, p. 264]. Зв'язок між образом та асоціацією в річищі лінгвістики вперше досліджено у працях 0.0. Потебні [4], який ставив за мету осмислити образну ментальну діяльність людини за допомогою мови. Однак, образ трактується дослідником як внутрішня форма художнього твору і розглядається лише на рівні слова [5, с. 98]. 3 цієї позиції 0.0. Потебня досліджував і внутрішню будову художнього образу, виділяючи такі його компоненти, як зміст, що відповідає чуттєвому образу, внутрішню форму - чуттєвий образ, з якого випливає зміст, та зовнішню форму, де об'єктивується художній образ. 
На відміну від 0.О. Потебні В.В. Виноградов трактує образ ширше та відносить його до текстового рівня: образ, утілений в одному слові або одній синтаксичній одиниці, може синтезувати в собі весь смисл художнього твору [6, с. 53].

Словесні образи є важливими конституентами художньої системи. Образ як конкретно-чуттєва даність виникає у свідомості людини стихійно [7, с. 73], натомість довільно створених словесних образів немає. Кожний словесний образ не існує сам по собі, а $є$ «вписаним у семантичний простір текстового світу, який, своєю чергою, $є$ частиною семіотичного простору культури» [8, с. 193].

У лінгвістиці словесний образ постає монолітною трьохчленною єдністю, складниками якої виступають значення, форма, зв'язок [7, с. 73]. Відтак словесним образам властиві не лише змістові характеристики, що виводяться 3 форми їх втілення у словесну тканину художнього тексту, а й асоціативні зв'язки. Тому в межах художнього тексту номінативні одиниці та словесні образи характеризуються взаємопроникненням їх значень [6, с. 55]. Утворення асоціативних зв'язків надає словесним образам або прямим номінаціям додаткових конотацій, декодування яких вимагає залучення та осмислення контекстуальної інформації.

Слідом за О.М. Мороховським, під словесним образом розуміємо слово, словосполучення або висловлення, що несе образну інформацію, значення якої не еквівалентно значенню окремо взятих елементів цього мовленнєвого відрізку [9, с. 38].

Відтак словесні образи відтворюють те, що не сприймається безпосередньо зоровою формою, а постає у свідомості у вигляді певного емоційно-асоціативного переживання, тобто те, що називають інтелектуальним або умоглядним образом [10, с. 102].

У світлі когнітивної лінгвістики з появою теорії концептуальної метафори словесний образ, а особливо словесний поетичний образ, слідом за Л.І. Бєлєховою, трактуємо як тривимірну величину, що інкорпорує передконцептуальну, концептуальну та вербальну іпостасі, будучи точкою перетину різних типів знань: архетипного, стереотипного й індивідуального [11, с. 189].

Поняття художнього образу є більш ширшим на відміну від словесного образу. У мовознавстві й літературознавстві художній образ постає специфічною формою відображення та пізнання дійсності. У вузькому розумінні художній образ позначає відтворення певної ідеї у формі конкретно-чуттєвого її зображення, 
позначеного рисами індивідуально-неповторної, глибоко-осібної манери світосприйняття [10, 97-99]. В основі художнього образу лежить конкретно-чуттєва даність предмета зображення $[12 ; 13 ; 9 ; 14]$, під якою розуміється сукупність індивідуальнопредметних ознак, що активуються в людській свідомості.

Загальна будова художнього образу в усіх видах мистецтва підпорядкована його двокомпонентній структурі - поєднання чуттєвого образу та його ідеї [10, с. 101]. Сам художній образ не може бути зведений лише до свого чуттєвого образу або його ідеї. Останні поняття є взаємопов'язаними: ідея виникає з чуттєвого образу, а образ уособлює цю ідею.

Художньому образу властиві, по-перше, емоційність, настанова на підкреслено-емоційний характер вираження тієї ідеї, формою втілення якої є чуттєвий образ; по-друге, узагальненість змісту, здатність уособлювати загальний зміст у формі одиничного, індивідуального, конкретно-чуттєвого; по-третє, суб'єктивність оцінок, тобто настанова на об'єктивне віддзеркалення дійсності у формі їі суб'єктивно-емоційного сприйняття [так само, с. 97-100].

3 огляду на зазначені характеристики визначаємо художній образ як індивідуальну форму відображення дійсності крізь призму конкретно-чуттєвої даності предметного зображення, що постає як форма узагальненого й суб'єктивно-емоційного вираження певної ідеї, думки.

Ще однією характерною художньому образу властивістю є його синкретичність, тобто здатність об'єднувати в собі інформацію про навколишній світ та відтворювати об'єкт у його цілісності [7, с. 73]. 3 цієї позиції вважаємо, що художній образ формується не лише за рахунок інкорпорації логічної інформації, яка міститься у прямих номінаціях, описах чи висловлюваннях персонажів, але й шляхом синтезу чуттєвої, образної інформації, що несе певну смислову значущість у художньому тексті.

Відтак трактування художніх образів тісно пов'язане 3 принципом кумулятивності. В.А. Кухаренко тлумачить художній образ як узагальнюючий, збірний, синтетичний, такий, що побудований на основі словесних образів, локалізованих у межах контексту [15, с. 59-69]. Словесні образи є першоелементами образів синтетичних, вони $\epsilon$ первинними за відношенням до художніх - вторинних $[16$, с. 11]. 3 цієї позиції О.А. Галич кваліфікує художні образи як «макро-образи» (образи-персонажі, образи- 
пейзажі, образи-інтер'єри, образи-оповідачі та ін.), а словесні образи як «мікро-образи» (тропи та синтаксичні фігури) [17, с. 100], розпорошені по всьому тексту.

Отже, сучасна лінгвістика розглядає поняття «образу» як конкретно-чуттєвої даності, художнього образу як вираження ідеї, узагальненого змісту художнього тексту та словесного образу як втілення ідеї та змісту у словесній формі $[18$, с. 3$]$.

\section{Лінгвокогнітивний підхід}

Розуміючи словесний образ у річищі когнітивної поетики (О.П. Воробйова, Л.І. Бєлєхова, О.М. Кагановська, В.Г. Ніконова, M. Freeman, R. Tsur, P. Stockwell) як тривимірну величину, що інкорпорує передконцептуальну, концептуальну та вербальну іпостасі [11], дослідження має бути спрямоване на моделювання концептуальної іпостасі словесних образів, необхідних для побудови художнього образу як такого.

У світлі теорії концептуальної метафори (M. Freeman, M. Johnson, G. Lakoff, M. Turner) та метонімії (Z. Kövecses) форматом репрезентації знань про художній образ постають моделі концептуальних метафор та метонімій як форми мислення, спосіб пізнання, структурування знання [19, р. 202-251].

Концептуальна метафора $\epsilon$ способом концептуалізації абстрактної або незнайомої сфери крізь призму конкретної або інтуїтивно близької в розумінні сфери [20, p. 288]. Традиційно концептуальну метафору трактують як проекцію (mapping) знань 3 царини джерела (source) на царину мети (target) через онтологічні відповідності між ними [19, р. 203]. Відтак концептуальна метафора постає результатом когнітивного процесу, який співвідносить референт з його корелятом або групою корелятів, що $\epsilon$ прагматично не пов'язаними або належать до різних функціональних доменів.

Своєрідність концептуальної метафори полягає в тому, що в її основі лежать не значення слів, а концепти, структури яких проектується одна на одну відповідно до певних онтологічних відповідностей.

Концептуальний аналіз семантики словесних образів передбачає процес реконструкції концептуальних метафор. Поперше, ідентифікацію царини мети, яка містить знання про об'єкт, що позначається, по-друге, ідентифікацію царини джерела, що охоплює знання про об'єкт, котрий використовується для 
позначення іншого об'єкта, по-третє, установлення смислових зв'язків між царинами джерела і мети.

Якщо для концептуальної метафори традиційною є дводоменна структура - царина мети й джерела, то метонімічне мапування відбувається в межах однієї царини [21, р. 59-60; 22, р. 37-77]. Так, концептуальна метонімія постає когнітивною моделлю, яка характеризується відношенням заміщення, що має місце в межах однієї з царин.

Утілення концептуальної структури у словесній тканині художнього тексту здійснюється через лінгвокогнітивну операцію мапування [23; 24], котра розглядається в когнітивній лінгвістиці як механізм концептуальної метафори, що пояснює шляхи створення концептуальних схем. Останні дозволяють по-різному структурувати й осмислювати зміст однієї і тієї ж когнітивної царини [25, р. 35]. Різні види мапування визначаються Л.І. Бєлєховою як лінгвокогнітивні операції, тобто дії, спрямовані на формування словесних образів, які супроводжуються лінгвокогнітивними процедурами - прийомами аналізу якостей та ознак, що містяться в царині джерела й мети словесних образів [11, с. 176].

У руслі лінгвокогнітивного аспекту операції та процедури постають лінгвокогнітивними механізмами формування словесних образів, що у свою чергу актуалізують художній образ.

Словесне втілення авторського задуму пояснюється через виявлення лінгвокогнітивних операцій формування образів у художніх текстах. При аналоговому мапуванні - це проектування онтологічних сутностей царини джерела на споріднені онтологічні сутності царини мети [11, с. $181 ; 26$, р. 254]. При субститутивному мапуванні має місце заміщення однієї структури знань іншою [11, с. 228-229]. Цей вид мапування $\epsilon$ операцією ідентифікації імплікативних зв'язків між варіантами референтів концепту царини та проектування їх на іншу сутність цієї ж царини словесного образу [там само]. При контрастивному мапуванні спостерігаємо зіткнення протилежних онтологічних властивостей різних царин [11, с. 228-229; 27, р.83]. При наративному мапуванні - це проектування певного сюжету чи мотиву на зміст образу [11, с. 233-236]. Сигналами наявності цього виду мапування слугують власні імена, які $\epsilon$ алюзією на певний сюжет чи тему світової культури. При конструктивно-творчому мапуванні йдеться про проектування потенційних синтагматичних й 
парадигматичних властивостей номінативних одиниць на семантико-синтаксичну структуру образу [11, с. 228-240]. На фонологічному рівні конструктивно-творче мапування виявляється в алітерації та асонансі, на морфологічному - у функціональній переорієнтації мовних одиниць, на синтаксичному - у відношеннях між номінативними одиницями словесного образу (повтори та паралельні конструкції).

Різні види мапування супроводжуються лінгвокогнітивними операціями конкретизації (розкриття внутрішньоформної концептуальної ознаки царини джерела чи мети), спеціалізації (смисловий розвиток поняття, утіленого в сутності царини джерела чи мети), модифікації (трансформація концептуальної схеми) [11, с. 206-208] та процедурами розширення, узагальнення, компресії (опущенні суттєвих зв'язків між сутностями однієї з царин образу), зіткнення (зіштовхування різних модальностей) як механізмів трансформації схемних образів царин джерела і мети $[11 ; 28 ; 29 ; 20]$. Завдяки цим лінгвокогнітиним механізмам пояснюються шляхи появи чи прирощення образу нового значення, запобігається його повтор.

Якщо словесний образ несе укорінені з позиції новизни знання, його концептуальна іпостась репрезентована конвенційними схемами [24, р.139] мислення, для реконструкції яких задіяна мінімальна кількість лінгвокогнітивних механізмів. Оновлені знання розширюють або руйнують звичні схеми мислення в силу використання нетрадиційних способів відображення світу, створюючи неконвенційні [24, р.139] (авторські) або ідіотипні [11, с. 31] схеми. Реконструкція останніх вимагає залучення одразу декількох лінгвокогнітивних операцій та процедур.

у межах дихотомії СВІЙ/ЧУЖИЙ як опозиції подібного та несхожого [30, с.37] розгортання концептуальних просторів, підгрунтям яких є конвенційні схеми мислення, буде сприйматися адресатом як СВОЄ, а простори, що базуються на оновлених ідіотипних схемах, - як ЧУЖЕ. Остання сфера осмислюється адресатом як нетрадиційне, альтернативне тому, що відображає реальність, яка не $\epsilon$ когерентною до пресупозицій читача чи певної соціальної групи [31, р. 88]. Це приводить до появи у свідомості адресата асоціативних або контрастивних зв'язків між словесними образами, активованими в різних художніх контекстах.

При осмисленні окремого словесного образу, відірваного від контексту, вистачає двопросторової моделі, де царини джерела 
й мети корелюють 3 ментальними просторами їхніх сутностей. Інтерпретація словесних образів, розпорошених у межах художнього контексту, потребує комплексного осмислення і образу, який може бути побудованим на декількох тропах одночасно, уособлюючи більше, ніж одну ідею, і тексту як цілісного утворення. Відтак для реконструкції концептуальної іпостасі деяких словесних образів недостатньо лише положень теорії концептуальної метафори. Необхідним $\epsilon$ залучення теорії концептуальної інтеграції або бленду.

Під концептуальною інтеграцією або блендом, слідом за Ж. Фоконьє та М. Тернером, розуміємо базову когнітивну операцію, що здійснюється за певною схемою на різних рівнях абстракції та має чітку структуру, до якої належать вхідні простори (input spaces), родовий простір (generic space) та змішаний простір (blend). У межах кожного бленду існує, принаймні, два вхідних ментальних простори, що співвідносяться 3 цариною джерела й цариною мети теорії концептуальної метафори [32 p. 207]. Проте багатопросторова модель (many-space model) Ж. Фоконьє та M. Тернера $\epsilon$ альтернативою дводоменній моделі (two-domain model) Дж. Лакоффа та М. Джонсона: комбінація вхідних просторів й родового простору разом з фоновими знаннями адресата породжує новий незалежний змішаний ментальний простір або бленд, який несе концептуальний продукт інтеграції [33, p. 47].

Бленди не тотожні жодному з вхідних просторів та не зводяться до суми їхніх елементів. Не всі елементи та відношення проектуються зі вхідних просторів у бленд. Останній переймає зі вхідного простору лише частину структури, тобто здійснюється вибіркова проекція. У змішаному просторі формується нова або емергентна структура шляхом інтеграції концептуального матеріалу вхідних просторів. Родовий простір містить атрибути концептів, які беруть участь у процесі реконструкції нового ментального простору та присутні в обох вхідних просторах. За рахунок цих атрибутів відбувається структурне вирівнювання елементів обох вхідних просторів. Між останніми існує міжпросторове мапування (cross-space mapping), тобто пошук можливих точок перетину сутностей, що співвідносяться, шляхом поєднання подібних елементів і прототипів (counterparts) [34, p. 308].

Когнітивні операції, які виникають у свідомості людини, спрямовані на поєднання мови та мислення шляхом різних видів 
мапування: проекційного, прагматично-функціонального та схематичного. В основі реалізації проекційного мапування лежить метафора, що грунтується на переході з царини джерела до царини мети. Парадигматично-функціональне мапування базується на метонімії та синекдосі шляхом співвідношення з двома категоріями об'єкта, об'єднаними парадигматичною функцією. Схематичне мапування актуалізується у випадку використання схем чи фреймів як формату репрезентації певної ситуації в контексті [35, р. 9-11].

У процесі інтеграції ментальних просторів кожен з атрибутів вхідних просторів вносить свій вклад у бленд, тобто відбувається «розпакування знань» [36, р. 288] з опорою на фонові знання адресата, що приводить до створення додаткової структури з емергентним значенням, від чого залежить загальний смисл словесного образу. Кількість ментальних просторів у мережі підпорядкована ідейному наповненню словесного образу і може варіюватися.

Таким чином, залучення концептуального аналізу семантики словесних образів, локалізованих у художній текстах, уможливлює реконструкцію концептуальних метафор й метонімій, емергентних структур у бленді, які реструктурують знання та досвід про відповідний художній образ, актуалізований в образних та прямих номінаціях. Однак для визначення концептуального виміру цього художнього образу положень концептуальної метафори, метонімії та бленду не достатньо. Відтак необхідним є залучення фреймів й світів.

\section{Когнітивно-комунікативний підхід}

Спільним поняттям, що лежить в основі провідних напрямів американської школи когнітивної лінгвістики в аспекті теорій концептуальної метафори (G. Lakoff, M. Johnson), концептуальних мереж та інтеграції (G. Fauconnier, M. Turner), схем (G. Cook, E. Semino), фреймової семантики (Ch. Fillmore), текстових світів (P. Werth, J. Gavins), вигаданих світів (C. Emmott), можливих світів (R. Adams, M. Ryan) та дейктичного зсуву (E. Segal, L. Talmy) $\epsilon$ концепція ментальних просторів - динамічних когнітивних структур, що виникають у свідомості людини як засіб осмислення семантичного простору художнього тексту.

теорія текстових світів, розвинута у працях П. Верта [37; 38], Є. Семіно [39], Дж. Гавінс [40; 41], Л. Хідальго Даунінг [42], П. Стоквелла [43] та ін., уможливила виявлення концептуального 
простору текстів різних жанрів, базуючись на лінгвістичному аналізі контекстуальних факторів.

Залучення теорії текстових світів до опису концептуального виміру певного художнього образу дозволяє виявити когнітивнопрагматичні властивості цього художнього образу, який виражений у текстах не лише образними, а й прямими номінаціями.

У світлі теорії текстових світів ментальний простір трактують як текстовий світ або сценарій, що виникає в людській свідомості при взаємодії з художнім текстом [44, р. 7; 39, р. 1; 38, p. 180]. Взаємодія при цьому як результат реальної чи художньої комунікації $\epsilon$ динамічним процесом, адже смисл, що постійно оновлюється у свідомості адресата, зумовлює активну реконструкцію нових текстових світів. Необхідною умовою існування текстового світу $\epsilon$ наявність хоча б одного адресанта (addresser) та адресата (addressee) [43, р. 136], сумарну діяльність яких у побудові ментального простору визначаємо, слідом за П. Вертом, як дискурсивну ситуацію [38, р. 51]. 3 огляду на те, що дискурсивний світ за письмової комунікації завжди $\epsilon$ «розщепленим» [41, p. 26], учасниками художньої комунікації завжди є автор та читач. Останні активно конструюють у свідомості текстові світи або сценарії завдяки взаємодії інформації художнього тексту зі знаннями учасників про навколишній світ $[39$, p. 1] та їх особистим культурно-детермінованим досвідом [42, p. 85], тобто їх когнітивною базою.

Третім конструктом теорії текстових світів за П.Вертом $\epsilon$ nidcвim (sub-world), котрий створюється в результаті певного відсторонення від параметрів базового текстового світу [38, р. 212]. На нашу думку, префікс $s u b$ дещо видозмінює семантику терміна та надає йому негативної конотації: виникає уявлення, що кожний новий текстовий світ підпорядковується базовому, але це не завжди так. Дж. Гавінс вважає більш прийнятним використання терміну «перемикання світу» (world-switching) [41]. Іншими словами, читач перемикається з одного світу на інший, що містить деякі зміни установлених параметрів, але не називає нового концептуального простору. У контексті дослідження використовуємо термін «похідний світ», адже таке формулювання акцентує увагу на текстовому світі, створеному від базового світу.

Отже, похідні світи, актуалізовані в художніх текстах, за принципами кумулятивності й цілісності утворюють у свідомості 
читача єдиний гештальт - базовий текстовий світ. Відтак зміст художнього образу породжується глобальною ментальною репрезентацією - базовим текстовим світом, за умови існування якого існує і сам художній образ.

Концептуальним каркасом текстового світу $\epsilon$ світотвірні елементи (worlds-building elements) та функціонально-прогресивні nропозицї (function-advancing elements) [43, р. 137], які актуалізують когнітивні механізми - фрейми та схеми - відповідальні за обробку та збереження інформації.

Функціонально-прогресивні пропозиції, на відміну від світотвірних елементів, яким властива статичність, передбачають розвиток та просування подій, сцен чи аргументів усередині текстового світу та реалізуються на рівні дієслівних фраз (passed by the house, went away quickly, said desperately, went in on tiptoe) [41, p. $60 ; 43$, p. $137 ; 38$, p. 191].

Світотвірні (дейктичні та референційні) елементи вказують на місцезнаходження та ідентифікують об'єкти, явища, процеси, до яких застосовується референція відповідно до просторово-часового контексту [38, р. 180].

Дейксис трактуємо як лінгвістичне поняття, що вживається для позначення функцій особових та вказівних займенників, граматичного часу та інших граматичних й лексичних ознак, які проектують просторово-часові координати й особові характеристики на прямі й образні номінації [45, p. 636-637]. У межах референції на адресанта вирази типу now, here або уоu несуть додатковий смисл, тобто інтенціонально насичену інформацію, обтяжену різними конотаціями [46, р. 115]. Традиційно їх позначають як дейктичні маркери або елементи.

У розумінні зарубіжних учених світотвірними є всі лінгвістичні засоби, що здійснюють референцію на складові елементи ситуаційного контексту, в якому має місце комунікація [39, р. 31]. Текстовий світ складається 3 таких структурних компонентів [47, p. 129-155] або параметрів [41, p. 36; 37, p. 183-184], як простір (spatial structure), час (temporal structure), дійові особи (narrative's participant structure) й об'єкти (object structure).

Просторові межі, дійсні чи уявні, можуть бути вербалізовані різними мовними засобами. Дж. Гавінс та П. Стоквелл виділяють серед просторових дейктиків локативи (at Coney Island, in a little district, upstairs) та просторові прислівники (there, thither, thence, 
here, hither, hence, far away), вказівні займенники або демонтративи (this, these, that, those), дієслова руху (come back, go away, run) [41, p. 36; 43, p. 45-46].

До засобів, що утворюють часові параметри, відносяться локативи (in the first Spring morning, on weekends, at midnight), прислівники часу (yesterday, today, tomorrow) та варіювання граматичним часом (I'm still feeling nervous now, although I gave up the situation three hours ago). До дейктичного (deictic) або абсолютного (absolute tense) часу належать Past Simple, Present Simple, Future Simple. Відносний час (relative tense) складають Past Perfect, Future Continuous, Present Perfect Continuous та ін. [41, p. 36-37; 43, p. 46].

Більш детальну інформацію, крім просторово-часових параметрів, надають дійові особи та об'єкти, що населяють текстовий світ. Вони репрезентовані власними іменами, іменниками й займенниками (Della, wife, she) [41, p. 37]. До дейктичних елементів також відносяться визначений артикль та певна референція в цілому (the queen, Sheba).

Усі ці дейктичні категорії (person, space, time) з позиції теорії дейктичного зсуву утворюються й осмислюються відповідно до дейктичного центру (deictic center) [48], відомого також під термінами origo [49], center [50] center of orientation [51].

3 позиції когнітивної психології під дейктичним центром розуміється особисте «Я» кожної людини, згідно з яким людина осмислює свої стосунки з усіма елементами, що входять до складу їі оточення, та взаємозв'язки між цими елементами. Дейктичний центр не є стабільньним та змінюється разом зі зміною мовця (narrator - character, character - character) (person deixis), часовими (time deixis) і просторовими (space deixis) змінами в художньому тексті $[43$, p.47]. Для більш наочного розуміння доцільним $€$ звернення до наступної ситуації: уявіть, що ви на безлюдному острові і знаходите на березі пляшку з посланням "Meet me here a week from now with a stick about this big" [48, p. 55]. Цей приклад ілюструє пряму залежність особових, часових та просторових дейктичних елементів від контексту.

Текстовий світ характеризується наявністю первинного (primary origo) та вторинного (secondary origo) дейктичних центрів, різниця між якими полягає в опозиції значень $I$ та уои, визначених семантичними особливостями належності (origo-inclusive) або неналежності (origoexclusive) до дейктичного центру [52, p. 212] (Рис. 1). 


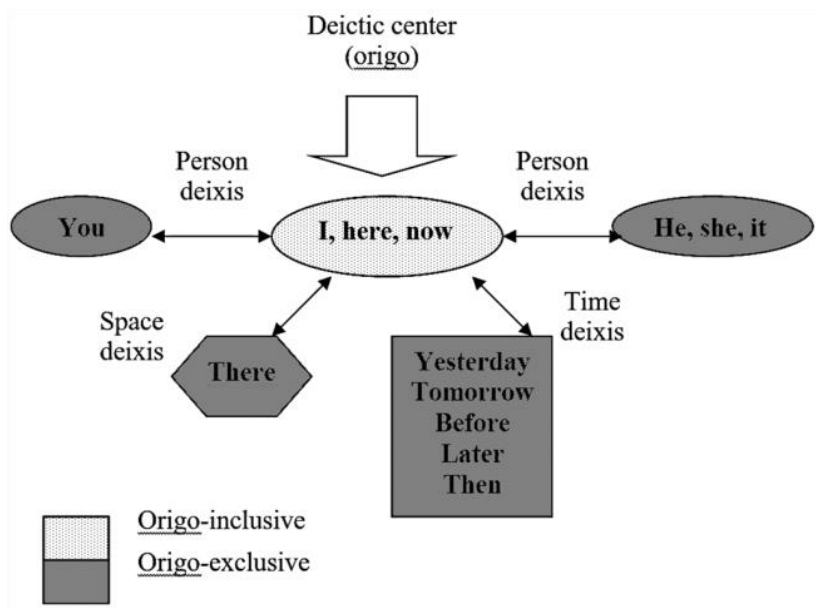

Рис. 1. Координати дейктичного центру

Так, I відноситься до дейктичного центру і виконує роль мовця (адресанта). Үои приймає роль мовця як адресат і знаходиться поза межами дейктичного центру. Отже, перша особа (I) використовується з метою референції як на адресанта, так і на дійову особу в межах текстового світу, друга особа (уои) є апеляцією до численних адресатів або дійових осіб, а третя особа (he, she, it) слугує референцією на об'єкти чи дійових осіб, що не беруть участі в дискурсивній ситуації, проте можуть бути присутніми чи неприсутніми, встановленими чи невстановленими в текстовому світі [53, p. 155]. Референція в художньому тексті може бути двох видів: екзофоричною (exоphoric) та ендофоричною (endophoric). Екзофорична референція виходить за межі тексту та $\epsilon$ фразою, якій характерне специфічне значення в межах контексту (the Queen Sheba). Ендофорична референція є посиланням усередині тексту, що може бути анафоричним (anaphoric) - до зазначеної інформації (Susan dropped the plate. It shattered loudly) та катафоричним (cataphoric) - до наступної порції інформації (He was very cold. David promptly put on his coat) [54, c. 84].

Слідом за Дж. Юлєм [46, р. 115], уважаємо, що дейктичні маркери типу this/that, now/then, here/there, як референція до адресата, використовуються автором задля досягнення перлокутивної мети 
комунікативної інтенції, а їх смисл може бути декодованим лише 3 урахуванням намірів адресанта.

Зв'язок між мовою та контекстом відображено у структурі самої мови не лише за допомогою дейктичних маркерів й референційних елементів, але й через залучення операторів модальності. Останні займають домінантну позицію в актуалізації текстових світів.

3 огляду на те, що вибір адресантом варіанта мовних i мовленнєвих одиниць для словесної тканини художнього тексту відбувається відповідно до його оцінки ситуації художньої комунікації та передбачуваної оцінки адресата, слідом за Дж. Гавінс, вважаємо за доцільне використання терміна модальний світ (modal world) [40, р. 87], адже цей світ є актуалізованим певним типом модальності та покликаним досягти перлокутивного ефекту впливу на читача в межах тексту. Остання є навмисною дією, за допомогою якої адресант використовує лінгвістичні форми, щоб уможливити ідентифікацію та оцінювання адресатом прагматично релевантної ситуації в контексті образних та прямих номінацій.

Категорія модальності трактується вітчизняними лінгвістами [55, с. 36; 56, с. 383] як функціонально-семантична категорія, що реалізується у двох видових значеннях: об'єктивно-модальному та суб'єктивно-модальному. На сьогоднішній день у фокусі уваги дослідників знаходиться не протиставлення об'єктивного й суб’єктивного аспектів модальності, а її комунікативний модус модус оцінки, знання, думки. 3 огляду на це модальність осмислюється як монолітна неподільна категорія, зміст якої складають суб'єктивні відношення, що асоціюються з адресантом. До того ж, проектуючи модальність на художній текст, можливим $€$ використання лише поняття суб'єктивна модальність, адже принцип реальності/нереальності зображених світів, характерний для об'єктивної модальності, не діє в художніх текстах: вони виражають лише суб'єктивне відношення до дійсності, переломлене крізь призму авторської свідомості.

Авторська модальність знаходиться у видовому положенні за відношенням до суб'єктивної модальності, а суб'єктом тексту виступає автор. 3 цієї позиції, слідом за I.В. Смущинською, визначаємо авторську модальність як різновид текстової категорії, що відображає суб'єктивно-оцінне ставлення адресанта до предмета художньої комунікації, його ціннісні орієнтири [57, с. 40]. Відповідно до вказаної дефініції незаперечним $є$ зв'язок авторської 
модальності з категорією інтенціональності, тобто комунікативнопрагматичною спрямованістю семантики художнього тексту, що залежить від комунікативних настанов автора, його емоційноетичної сфери. Саме цим пояснюється вибір необхідних лексичних, граматичних, фразеологічних, синтаксичних або стилістичних засобів вираження намірів адресанта. Так, авторська модальність постає як вияв когнітивно-аксіологічних процесів у свідомості адресанта, його відношення до інформаційного складника текстів та як певний комунікативний «сигнал» для адресата [58, с. 195]. Це положення $\epsilon$ дуже актуальним для нашого дослідження, адже залучення адресантом певних модальних засобів зумовлено його особистісними настановами, немовленнєвими завданнями, виявлення яких уможливить виведення складного прагматичного смислу, необхідного для реконструкції модальних світів, максимально наближених до авторських.

Засновником концепції модальності в західноєвропейській лінгвістиці традиційно вважається Ш. Баллі, на думку якого будь-яке висловлювання містить основний зміст (диктум) та його модальну частину (модус) як відображення емоційного-оцінного чи вольового судження адресанта за відношенням до диктуму [59, с. 44], адже не існує цілком об'єктивного тексту [60, р. 76]. Концепція Ш. Баллі була розвинута у працях Н. Решера [61], Дж. Лайона [45], Дж. Коутса [62], К. Хенгевельда [63], Ф. Палмера [64], П. Сімпсона [65] шляхом виділення різних типів модальності відповідно до функціональносемантичного розмежування іï модусів. Загалом, поняття модальності пов'язують 3 відношенням адресанта до пропозиції, утіленої у прямих та образних номінаціях [45, р. 456; 65, р. 47].

У руслі теорії текстових світів та в контексті нашого дослідження спираємося на класифікацію П. Сімпсона [65], який диференціює усі емоційно-оцінні ознаки мови за трьома категоріями модальності деонтичною (deontic), буїлистичною (boulomaic) та епістемічною (epistemic), - кожна з яких слугує засобом відображення авторських інтенцій. Інтенція, на думку Г. Грайса, є наміром адресанта донести свою думку, її суб'єктивний смисл до адресата [66, р. 378].

Так, деонтична модальність пов'язана з поняттям дозволу та почуттям обов'язку [45, р. 823; 65, р. 47], виражаючи необхідне, доцільне або дозволене відповідно до соціальних, моральних, юридичних та інших принципів. Будучи спрямованим на дію, цей тип модальності не прогнозує її реалізацію, а лише передає заклик 
до виконання дії. Крім цього, деонтична модальність може відображати пораду чи рекомендацію, виконуючи, таким чином, функцію соціальної взаємодії.

Буїлистичну модальність трактують як ступінь схвалення або несхвалення адресантом дійсного стану справ [67, р. 12], відображеного в дієгетичній реальності, шляхом вираження його бажань, намірів та сподівань [61, p. 24; 65, р. 48]. К. Хенгевельд виділяє буїлистичну модальність як підтип суб'єктивної модальності, яка визначає орієнтацію адресанта стосовно ступеня бажання чи сподівання в межах його епістемологічної системи [63, p. 139]. У роботі, слідом за І.В. Смущинською [68], уживаємо термін «авторська модальність», який, на нашу думку, краще відображає суб'єктивність відношення до дійсності в художньому тексті.

Епістемічна модальність виражає впевненість або невпевненість адресанта у правдивості вислову [62, р. 18; 65, p. 48] через репрезентацію його знань, думок, припущень відповідно до окремих фактів [45, р. 793]. Уживання епістемічної модальності в художньому тексті закладає епістемічний модальний світ, котрий репрезентує ситуацію, що не може бути реалізованою в тих часових й просторових межах, які цю ситуацію породжують [41, р. 110], проте є можливою або неможливою в майбутньому. Відзначена ситуація кваліфікується гіпотетичною (hypothetical) або віддаленою (remote) [64]. Модальні світи, актуалізовані будь-якою формою епістемічної модальності, відрізняються від деонтичних та буїлистичних світів тим фактом, що епістемічні модальні світи завжди мають додатковий відтінок нереальності, що робить їх найвіддаленішими від базового текстового світу.

Якщо деонтична модальність виражає обов'язок, буїлистична або авторська передає бажання й оцінку, то епістемічна модальність сигналізує про рівень знань адресанта щодо дійсності певного вислову [41, р. 112]. Загалом, графічне відображення місця модальності в передачі авторських інтенцій та реконструкції модальних світів графічно відображене в рис. 2.

Реконструкція модальних світів уможливлює комплексну інтерпретацію адресатом тексту як цілісного утворення, враховуючи інформацію, яка може бути вилучена на всіх рівнях організації тексту.

3 метою привернення уваги адресата будь-яка мовна одиниця може зазнати образних й емоційних трансформацій, тобто 
одержати в межах художнього контексту статус маркера суб'єктивної модальності. Заміна хоча б одного модального індикатора приводить до утворення нового модального смислу. Проте значну роль у відображенні суб'єктивного відношення адресанта до реальності відіграють стилістичні засоби та прийоми, які слугують матеріалом для побудови словесних образів та можуть бути задіяні одразу на декількох рівнях тексту для підвищення загальної образності або втілення одразу декількох ідей.

Таким чином, у межах семантики художніх текстів словесні образи більше, ніж прямі номінації, реалізують «інший» смисл, адже тропеїчне мовлення, що лежить в основі їх (образів) утворення, висловлює «понадреальний» зміст через уживання ненормативних засобів й специфічних зворотів [69, с. 33]. Відповідно до нашого дослідження у фокусі аналізу знаходяться ті словесні образи, у семантиці яких через певний тип модальності (деонтичної, авторської чи епістемічної) виражена певна оцінка чи актуалізовані релевантні ознаки концептуальної іпостасі відповідного художнього образу.

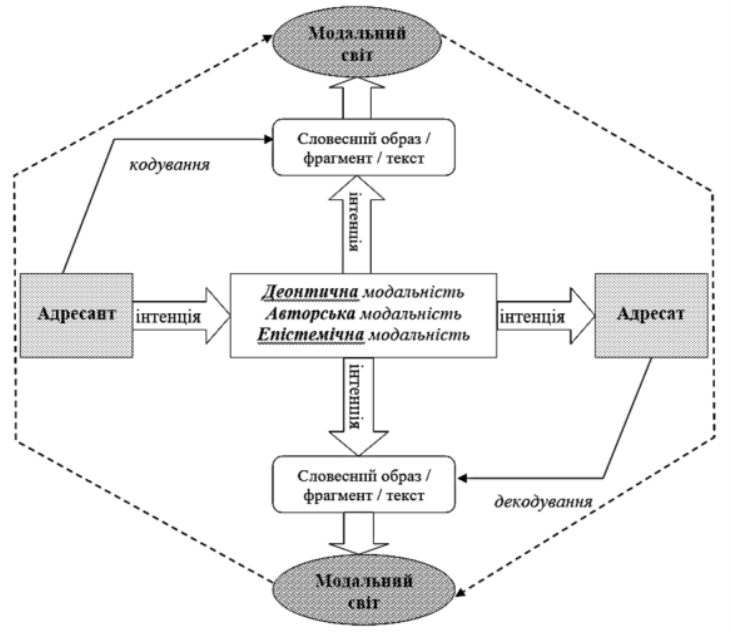

Рис. 2. Схема реконструкції модальних світів з позиції когнітивно-прагматичного аспекту 
Доходимо висновку, що текстовий світ спочатку окреслюється дейктичними, референційними елементами та операторами модальності, установленими в тексті, а вже потім розширюється завдяки знанням, структурованим фреймами та схемами.

Використання нами фреймового підходу для моделювання концептуальної іпостасі художнього образу обумовлено центральною функцією фреймів, в основі якої лежить психологічна концепція пам'яті та особливості свідомості людини, - оцінювання й прогнозування нової ситуації шляхом зіставлення ії̈ з попередньо сформованими знаннями, досвідом [70, p. 16-17; 71, р. 37-39] та пов'язаною з ним інформацією [72, р. 198]. У системі художньої комунікації адресант - текст - адресат останній інтерпретує зміст отриманих знань відповідно до певної стереотипної ситуації (інтеракції) [73, р. 27] як частини когнітивного фону, який відповідає за динамічність розгортання текстового світу [42, р. 117].

На рівні тексту фрейм постає стереотипною ситуацією 3 попередньої текстової традиції, яка $є$ актуалізованою у конкретному художньому мовленні. Доцільність використання саме фреймового моделювання для виявлення концептуальної іпостасі художнього образу зумовлена такими ознаками фреймів, як відображення різнорідних знань, ієрархічна структура, часткове заміщення один одного, осмислення й оцінювання нової інформації [38, р. 106-107].

Як «пакети інформації» [74, р. 29], що активуються в художньому мовленні, фрейми структуруються певною кількістю доменів та постають у вигляді пропозицій [75, с. 178]. Домен визначається як когнітивна царина, сфера або контекст [76, р. 3], який лежить в основі ключової репрезентанти концепту та забезпечує його розуміння [77, с. 88]. Сукупність доменів, які одночасно активуються певним концептом (профілем), є його концептуальною матрицею або базою [78, р. 147, 183]. У контексті профілювання П. Стоквелл та Дж. Тайлер трактують ці поняття як фігуру (профіль)

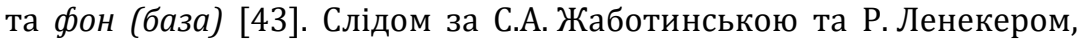
трактуємо домен як зв'язну область концептуалізації, відносно якої встановлюється значення мовного знаку [78, р. 488].

Підсумовуючи зазначене, уважаємо, що будь-який художній образ формується паралельно до розгортання базового текстового світу або концептуального сценарію, що інкорпорує похідні світи, актуалізовані в семантиці текстів дейктичними й референційними 
елементами, операторами суб'єктивної модальності, утіленими у прямих та образних номінаціях.

\section{Комунікативно-прагматичний підхід}

У річищі комунікативної парадигми основна увага надається комунікативній діяльності та впливу на цю діяльність контексту іiї реалізації, способам вираження інтенцій та настанов учасників комунікації.

Художня комунікація визначається як інтеракція, у процесі якої виникає трансляція та осмислення культурних смислів, взаємовплив її учасників - автора й читача. 3 огляду на те, що прагматика автора базується на відношеннях автор - текст, а прагматика читача - текст - читач [79, с. 120], поняття смислу має подвійну природу: з точки зору автора смисл $\epsilon$ інтенціональною, ілокутивною складовою, тоді як для читача смисл постає психокогнітивною реакцією на інтенції адресанта [58, с. 18].

Особливістю художньої комунікації як непрямого типу комунікації $\epsilon$ iї обтяженість імпліцитними смислами вербалізованих прямих й образних номінацій, що свідомо закладаються автором, розраховуючи не лише на їх декодування читачем, а й на досягнення ними перлокутивного ефекту. Останній трактують як посткомунікативний ефект, який спричиняє прямі або побічні зміни у свідомості адресата та оцінюється на основі тих наслідків, котрі він зумовлює [80, с. 56].

3 позиції теорії мовленнєвих актів [81; 82] основною одиницею комунікації $\epsilon$ не речення чи вислів, а виконання певної дії, реалізованої в питанні, ствердженні, проханні, тощо, що дістало назву мовленнєвих актів. В основі прямого мовленнєвого акту лежить одна ілокутивна сила (інтенціональне значення), виражене граматичними й лексичними засобами. У непрямому акті присутня більше, ніж одна ілокутивна сила, тобто на фоні експлікованої (яскраво вираженої мовними засобами) ілокутивної сили з'являється інша, що приводить до утворення додаткового смислу в мовленнєвому акті [83, с. 7-11].

3 позиції цього підходу художній текст трактується багатьма вітчизняними науковцями як аналог мовленнєвого акту, що володіє такими прагматичними параметрами, як адресант або автор художнього мовлення, його комунікативна настанова (інтенція), адресат або «масовий читач» і пов'язаний з ним перлокутивний ефект [84, с. 118-119]. 
Художній комунікації, як і реальній, властивий діалогічний характер, а мовленнєві акти в художньому тексті також знаходять свою реалізацію. Відповідно до непрямого способу передачі інформації мовленнєвою одиницею художньої комунікації $\epsilon$ непрямий мовленнєвий акт, декодування смислу якого вимагає додаткових зусиль інтерпретації 3 боку читача. У контексті дослідження вважаємо, що непрямий мовленнєвий акт є тотожним такій образній номінації в художньому тексті, як словесний образ, адже має спільну з ним функцію - непряме вираження інтенції, бажання адресанта уникнути прямого ствердження ілокутивної мети в межах вислову. 3 огляду на те, що непряме інформування адресата вимагає звернення до різноманітних форм непрямої передачі інформації [58, с. 225], засобами втілення непрямих мовленнєвих актів, як і словесних образів, у тексті $є$ тропи. Отже, в умовах опосередкованої комунікації досягнення необхідного комунікативного ефекту можливе лише шляхом особливої організації макроструктури тексту на всіх його рівнях.

Стилістичні фігури та прийоми $€$ об'єктом вивчення прагмастилістики, у фокусі аналізу якої знаходяться такі ключові положення:

1) вплив інтенцій, стратегій і тактик адресанта/автора тексту на вибір образних засобів мови;

2) взаємодія інтенції, стратегії та тактики мовця й стилю його мовлення;

3) авторські інтенції, стратегї та тактики як основа формування індивідуально-художнього стилю письменника [85, с. 9-10].

Взаємодія лінгвальних факторів 3 екстралінгвальними відбувається через прагматику цілого тексту або низки текстів, у зв'язку 3 чим прагматичним аспектом словесних образів як непрямих мовленнєвих актів $\epsilon$ відношення між мовленнєвими знаками та учасниками художньої комунікації. Успішність декодування імпліцитних смислів залежить більшою мірою від екстралінгвістичної компетенції адресата, адже семантичні прирощення у непрямих мовленнєвих актах $\epsilon$ прагматично релевантними для нього [80, с. 57-58].

Предметом аналізу лінгвопрагматики в межах художнього тексту постають інтенції, немовленнєві завдання та наміри автора, опредметнені у словесній тканині прямих й образних номінацій; імпліцитні смисли, які можуть стояти як за окремими лексичними 
одиницями, так і за цілими макроконтекстами; стратегії і тактики як перспектива відбору й адаптації адресантом інформації, що віднаходить у тексті художньо-естетичне осмислення.

На сучасному етапі розвитку мовознавчої науки лінгвопрагматика синтезувала в собі теорію мовленнєвих актів, теорію референції й релевантності, ключові положення прагматики, розширивши таким чином свій методологічний апарат, який дозволяє аналізувати смисли та виявляти функції впливу, інтеракції таких одиниць, що раніше були поза фокусом її уваги: дейктичні та референційні маркери, вигуки, частки, сполучники та ін. Нарівні зі словесними образами ці номінативні одиниці $є$ не менш прагматично релевантними в побудові художнього образу.

Отже, актуальним положенням у вивченні комунікативнопрагматичного аспекту художнього образу є розкриття механізму не стільки мовленнєвої діяльності, скільки мовленнєвого впливу адресанта на адресата через прямі й образні номінації, що уможливить установлення комунікативно-прагматичних властивостей певного художнього образу.

Основним компонентом мовленнєвої діяльності в межах художньої комунікації $€$ паралінгвістичний компонент, який забезпечує мотиваційний момент, момент інтенції [80, с. 50]. Інтенції формують психологічний зміст мовлення особистості і можуть бути глибоко прихованими. На виявлення інтенцій спрямований інтент-аналіз, який спирається на проникнення в експліцитні й імпліцитні комунікативні смисли непрямих мовленнєвих актів [58, с. 41]. 3 огляду на те, що в межах художнього тексту виділяють два види комунікації вертикальну (між автором й читачем) та горизонтальну (між персонажами), необхідним є розмежування двох видів інтенцій художнього твору - авторських інтенцій та інтенцій персонажів. Останні $€$ завжди підпорядкованими авторським інтенціям, які реалізуються для досягнення комунікативної мети. Комунікативна мета завжди $\epsilon$ імпліцитно вираженою та інкорпорує весь прагматичний смисл тексту шляхом реалізації низки комунікативних стратегій [86, с. 121].

У світлі лінгвопрагматики стратегію інтерпретують як вибір адресантом способу комунікації [87, s. 15], як оптимальний засіб досягнення комунікативної мети за рахунок певних мовленнєвих дій адресанта [88, с.50]. Такі дії трактують як комунікативні тактики або прийоми реалізації стратегії, спрямовані на вирішення 
одного комунікативного завдання в межах однієї стратегічної мети [86, с. 278]. При цьому комунікативна тактика, на відміну від комунікативної стратегії, $€$ співвіднесеною не з комунікативною метою, а з інтенціями адресанта як з практичними засобами руху до відповідної комунікативної мети [89, с. 11].

3 позиції художньої комунікації доцільним $€$ використання терміну «комунікативна стратегія», замість «мовленнєва стратегія». Останнє поняття є більш вужчим, адже до складу мовленнєвої стратегії не входять екстралінгвістичні компоненти комунікативної взаємодії, характерні комунікативній стратегії. На виявлення стратегій і тактик спрямований прагмасемантичний аналіз, що полягає у вивченні людських вимірів комунікації, спираючись на засоби мовного коду [58, с. 41].

Відтак в аспекті комунікативно-прагматичного підходу головним фактором формування художнього образу є прагматика мовця (автора, оповідача, персонажа), тобто настанова на використання тих чи інших прямих й образних номінації (тропів й стилістичних фігур) в межах комунікативних стратегій, підпорядкованих кінцевій комунікативній меті.

\section{Комунікативно-наративний підхід}

Єдність комунікативної та наративної парадигм мовлення ставить у фокус уваги дослідників адресованість художнього мовлення, адже головною характеристикою будь-якого твору $є$ його звернення [90, с. 279]. Це положення підтверджує, що сучасна лінгвістика відійшла від тенденції досліджувати художні тексти лише з позиції адресанта і почала аналізувати їх з боку адресата як об'єкта сприйняття.

Адресованість до співрозмовника, орієнтація на його потенційну реакцію, бажаний психологічний ефект $\epsilon$ обов'язковою умовою досягнення перлокутивного ефекту повідомлення. О.П. Воробйова трактує «адресованість» як орієнтацію на гіпотетичного адресата, що постає «згустком» суспільних стосунків, іншою щодо автора особистістю, яка задає конкретну модель інтерпретації дискурсу та слугує семантичною базою для сприйняття тексту [91, с. 79]. На наш погляд, термін «гіпотетичний адресат» не $\epsilon$ коректним у ролі наративної інстанції саме художньої комунікації і потребує уточнення з позиції комунікативно-наративного підходу. 
У руслі комунікативно-наративного аспекту художній комунікації властиві такі самі прагматичні параметри, як і реальній комунікації: автор/адресант мовлення, його прагматична мета, читач/адресат і пов'язаний з ним перлокутивний ефект. Посередниками художньої комунікації в межах художнього тексту є наратор і персонаж, яким і належить будь-яке висловлювання в тексті [92, с. 68].

Однак художня комунікація відзначається складною структурою, що включає в себе наративну та авторську комунікації. у межах художнього тексту відбуваються одночасно два комунікативні процеси - внутрішній та зовнішній: оповідь історії (наратором) та реалізація мовленнєвого акту (автором) [93, с. 34]. При цьому авторська комунікація $\epsilon$ ширшою і включає в себе наративну комунікацію як складову дієгетичної реальності.

Зовнішня або авторська система комунікації містить такі наративні інстанції, як «конкретний автор» - «конкретний читач», «абстрактний/ імпліцитний автор» - «абстрактний/ імпліцитний читач».

Конкретний автор є реальною історичною особою, яка існує незалежно від художнього тексту. Конкретний читач також існує окремо і незалежно від тексту [93, с. 41]. Під конкретним читачем розуміємо нескінченну множину реальних людей, для позначення яких доцільніше використовувати термін «масовий читач» [94, с. 66].

Імпліцитний автор є складною наративною інстанцією, що свідомо обирає та застосовує комунікативні стратегії, тактики й прийоми, створює наратора і персонажів у тексті [95, с. 46], тобто створює імпліцитну версію самого себе. Імпліцитний [96] або абстрактний читач [93] постає іпостассю уявлень конкретного автора щодо свого читача [93, с. 57], єдність попередніх спрямувань автора, репрезентованих у художньому тексті [96, s. 60]. Імпліцитний читач виконує дві функції: передбачуваного адресата, до якого спрямовані всі мовні коди й мовленнєві підказки, ідеологічні норми й естетичні уявлення, та ідеального реципієнта, який переймає смислову позицію тексту [93, с. 61]. За цією ж функцією У. Еко використовує термін ідеальний читач [97, р. 92], під яким розуміє активного до співпраці адресата, здатного повністю відтворити потенційний смисл тексту. На відміну від реального читача, ідеальний читач $є$ завжди абстрактним поняттям.

у нашому дослідженні використовуємо термін «ідеального читача» як комунікативно-наративної інстанції, до якої спрямовані 
усі непрямі мовленнєві акти в межах художньої комунікації, репрезентовані в тексті словесними образами. Відповідно реконструкція текстового світу, який лежить в основі розгортання будь-якого художнього образу і $€$ максимально наближеним до авторського, здійснюється саме ідеальним читачем.

Внутрішня або наративна комунікація охоплює такі ключові інстанції, як «антропоморфний наратор» / «неантропоморфний наратор», «експліцитний наратор» - «імпліцитний наратор», «дієгетичний наратор»/ «недієгетичний наратор». Сам термін «наратор» трактуємо як синтезувальну текстову категорію, що $\epsilon$ епіцентром тексту, індивідуальною мовленнєвою структурою, яка пронизує всю архітектоніку / композицію художнього тексту й визначає кореляцію всіх його складників [98, с. 55].

Антропоморфність/неантропоморфність наратора визначається його репрезентацією в дієгетичній реальності художнього тексту з позиції людини або будь-якої іншої істоти.

Експліцитний наратор об'єктивує себе в тексті, називаючи своє ім'я, змальовуючи свою зовнішність тощо. Реалізація імпліцитного наратора у словесній тканині тексту досягається через добір наративного матеріалу та деталізацію його елементів, оцінку, роздуми та коментарі [93, с. 19-23].

Дихотомія дієгетичний/недієгетичний наратор характеризує присутність наратора в дієгезисі (план історії, що оповідається) та екзегезисі (плані оповіді) [99, p. 157]. Так, дієгетичний наратор оповідає про самого себе як фігуру в дієгезисі, знаходячись і в плані оповідання як його суб'єкт, і в історії, яка оповідається, як її об’єкт. Недієгетичний наратор фігурує лише в екзегезисі [93, с. 81]. Крім цього, опозиція дієгетичний/недієгетичний наратор репрезентована в тексті оповіддю від 1 або 3 особи. Засобами вираження суб'єктивно-мовленнєвої складової недієгетичного наратора $\epsilon$ регулярне використання форм теперішнього часу, особливо в контексті ретроспективи, актуалізація біблійних чи міфологічних мотивів, стилістично зниженої лексики тощо.

Отже, в межах внутрішньої комунікації наратор може бути вираженим експліцитно чи імпліцитно, бути наділеним якостями людини, бути об'єктом та суб'єктом історії, яка оповідається, або об'єктивною інстанцією, голосом ззовні.

Актуалізація в художньому тексті різних планів нарації пов'язана з різними ознаками художнього мовлення. Вирізнити 
суб'єктивно-мовленнєві ознаки оповіді можливо за допомогою окремих лінгвістичних й стилістичних маркерів: форм займенників, граматичного часу, особових форм дієслова, семантично дифузних лексем тощо.

Однак використання навіть таких дрібних дейктичних одиниць, як морфеми, не лише впливає на прагматичний смисл окремих словесних образів, задіяних у побудові художнього образу, але іє підпорядкованим загальній комунікативній меті художнього тексту.

3 огляду на те, що інформація в художньому тексті репрезентована опосередковано, крізь призму, фокус чи точку зору наратора (експліцитного й імпліцитного) або персонажа, при реконструкції текстового світу, необхідним є звернення до поняття фокалізації (focalization) - вибору наративної інформації за відношенням до авторського «всезнання» [99, р. 49]. Фокалізація структурує об’єкти та події дієгетичної реальності в такий спосіб, що у процесі інтерпретації тексту вони постають як результат відбиття певної точки зору та системи контекстуальних координат [100, p. 301-303]. Слідом за Ж. Женетт [99], уважаємо доцільним використання терміну «фокалізація» на відміну від «точка зору», адже першому властиві радше абстрактні конотації, ніж візуальні [99, р. 79-82], включаючи когнітивну, емотивну та ідеологічну специфіку [101, р. 71].

Явище фокалізації не є вербалізованим, проте реалізується воно в художньому тексті саме через мовлення персонажа й наратора [102, p. 198-199, 205, 218]. Відповідно до зазначеного фокалізація може бути внутрішньою (internal), зовнішньою (external) або нульовою (zero).

Внутрішня фокалізація репрезентована з позиції персонажа, який виступає наратором [103, р. 45]. При цьому у фокусі наратора знаходиться те, що «бачить» персонаж. Проблематичним $€$ визначення дистанції між наратором та абстрактним автором, що обумовлено зниженою емоційністю тексту. Якщо позиція персонажа не є уособленою (імпліцитний наратор), вона насичена його психологічними вадами настільки, що достатньо лише когнітивно «оформити» у першій особі, щоб дійти висновку: предметом фокалізації виступає персонаж. Цей тип фокалізації (рис. 3.) обумовлює особливості реконструкції базового текстового світу художнього образу, який буде складатись з похідних світів, доступних персонажам (character-accessible worlds), тобто таких, що 
мають подвійне кодування (накладання когнітивної бази автора на когнітивну базу персонажа).

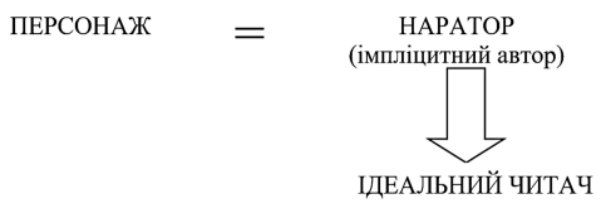

\section{Рис. 3. Внутрішня фокалізація}

При зовнішній фокалізації має місце «погляд ззовні»: художня інформація репрезентована з точки зору об’єктивного наратора, позбавленого доступу до свідомості персонажа [93, с. 113], тобто «наратор знає менше, ніж персонаж» [102, р. 204]. Таким чином, у фокусі наратора знаходиться сам персонаж. Відповідно до цього типу фокалізації (рис. 4.) базовий текстовий світ буде складатися 3 похідних світів, доступних учасникам художньої комунікації (задіяна когнітивна база автора).

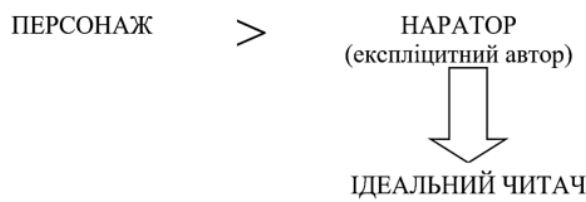

\section{Рис. 4. Зовнішня фокалізація}

За нульової фокалізації психологічна й темпоральна дистанції між наратором та персонажем $\epsilon$ мінімальними, тобто дейктичний центр постійно переходить від наратора до персонажа. Проте більша й значуща частина інформації в художньому тексті репрезентована саме через мовлення наратора: «наратор володіє більш грунтовним знанням, ніж персонаж» [102, p. 204], тобто $\epsilon$ всезнаючим й всюдисущим. Такий тип фокалізації (рис. 5.) визначає відмінності в реконструкції базового текстового світу художнього образу, який буде складатися 3 похідних світів, доступних i персонажам, і учасникам художньої комунікації. 


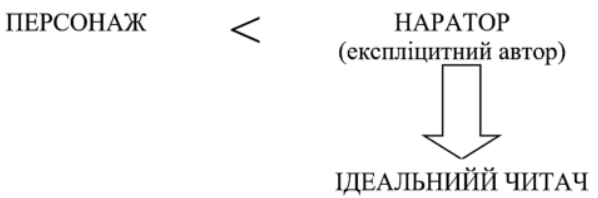

\section{Рис. 5. Нульова фокалізація}

Фоказілація уможливлює художню комунікацію як таку, що реалізована у глибині проникнення читача в текстовий світ автора.

У контексті нашого дослідження залучення фокалізації до визначення різних планів нарації у художніх текстах дозволить виявити комунікативні стратегії не лише як відповідні перспективи «прочитання» тексту, тобто декодування його прагматичного смислу, а й як комунікативно-прагматичні механізми формування будь-якого художнього образу.

\section{Висновки}

Критичний аналіз наукової літератури 3 теорії художнього образу засвідчив, що поняття образу є достатньо вивченим з позиції різних парадигм сучасної лінгвістики, проте деякі його положення виявляють перспективу до подальших досліджень.

На підставі аналітичного огляду доробків щодо вивчення художнього образу трактуємо це поняття як індивідуально-авторську форму відображення дійсності крізь призму конкретно-чуттєвої даності предметного зображення, що постає як форма узагальненого й суб'єктивно-емоційного вираження певної ідеї, думки.

У річищі когнітивної парадигми основним здобутком для когнітивної теорії образу стали положення про концептуальну метафору й метонімію, концептуальну інтеграцію або бленд, що уможливили виявлення лінгвокогнітивних механізмів формування словесних образів. У руслі комунікативної парадигми вирішальним для концепції мовленнєвих актів стало положення про непрямі мовленнєві акти, яке в нашому дослідженні застосовується відповідно до художньої комунікації наступним чином: непрямі мовленнєві акти співвідносимо 3 образними номінаціями або словесними образами за спільною функцією непрямого вираження інтенції, бажання уникнути прямого ствердження ілокутивної мети в художньому тексті. У фокусі когнітивно-комунікативного підходу, 
який об'єднує лінгвокогнітивний та комунікативно-прагматичний аспекти дослідження художнього образу, знаходиться положення про текстові світи, що дозволяє реконструювати концептуальний простір текстів різних жанрів, базуючись на лінгвокогнітивному аналізі контекстуальної інформації. Охоплюючи ключові положення лінгвопрагматики про інтенції й немовленнєві завдання автора, стратегії й тактики, підпорядковані кінцевій комунікативній меті, та наратології щодо фокалізації як засобу визначення різних планів нарації в художньому тексті, залучення теорії текстових світів у контексті нашої роботи уможливлює виявлення когнітивнопрагматичних властивостей художнього образу.

\section{Список використаних джерел:}

1. Кант И. Всеобщая естественная история и теория неба : в 6-ти т. Москва : Мысль, 1963. Т. 1. С. 115-262.

2. Гегель Г. Эстетика : в 4-х т. Москва : Искусство, 1968. Т. 1. 312 с.

3. Galperin I. R. Stylistics. - Moscow : Higher School, 1977. 332 p.

4. Потебня А. А. Мысль и язык. Харьков : Типография Мирный труд, 1913. 225 с.

5. Потебня А.А. Слово и миф. Москва : Правда, 1989. 623 с.

6. Виноградов В.В. О теории художественной речи. Москва : Высшая школа, 1971. 240 с.

7. Арутюнова Н.Д. Образ, метафора, символ в контексте жизни и культуры. Филологические исследования. Памяти академика Г.В. Степанова. 1990. С. 71-88.

8. Бєлєхова Л. І. Інтегративна модель інтерпретації поетичного тексту (на матеріалі американської поезії). Науковий Вісник кафедри ЮНЕСКО Київського державного лінгвістичного університету. 2001. №. 3. С. 193-199.

9. Мороховский А. Н. Стилистика английского языка. Київ : Вища школа, 1991. 272 с.

10. Назарець В. М. Літературно-художній образ. Теорія літератури. 2001. С. 96-176.

11. Бєлєхова Л. І. Образний простір американської поезії: лінгвокогнітивний аспект : дис. ... д-ра філол. наук : 10.02.04. Київ, 2002. 476 с.

12. Борев Ю. Б. Эстетика. Москва : Высш. шк., 2002. 511 с.

13. Волков И. Ф. Теория литературы. Москва : Просвещение, 1995. $256 \mathrm{c.}$ 
14. Рудяков Н. А. Поэтика. Стилистический анализ художественного произведения. Симферополь: Таврия, 1993. 144 с.

15. Кухаренко В. А. Кумулятивный образ и связность текста. Вісник КНЛУ. 2011. № 1. С. 59-69.

16. Кухаренко В. А. Інтерпретація тексту. Вінниця : Нова Книга, 2004. 272 c.

17. Галич О. А. Теорія літератури. Київ : Либідь, 2001. 455 с.

18. Бєлєхова Л. І. Образний простір американської поезії: лінгвокогнітивний аспект : автореф. дис. ... д-ра філол. наук : 10.02.04. Київ, 2002. 34 с.

19. Lakoff G. The contemporary theory of metaphor. Metaphor and Thought. 1993. - P. 202-251.

20. Lakoff G. Women, Fire and Dangerous Things. What Categories Reveal About the Mind. Chicago : The University of Chicago Press, 1987.614 p.

21. Grady J. Frame-Internal Relations and the Distinction between Metaphor and Metonymy. 6th International Cognitive Linguistics Conference : Stockholm, Sweden 10-16 July, 1999. Stockholm: Stockholm Un-ty Press, 1999. P. 59-60.

22. Kövecses Z. Metonymy: Developing a Cognitive Linguistic View. Cognitive Linguistics. 1998. № 9 (1). P. 37-77.

23. Уфимцева Н. В. Семантика слова. Аспекты семантических исследований. 1980. С. 5-80.

24. Lakoff G., Johnson M. Metaphors We Live By. Chicago : Chicago University Press, 1980. 242 p.

25. Langacker R. Foundations of Cognitive Grammar. Descriptive Application. Stanford, CA : Stanford University Press, 1991. - 395 p.

26. Freeman M. Poetry and the scope of metaphor: Toward a cognitive theory of literature. Metaphor and Metonymy at the Crossroads. A Cognitive Perspective. 2000. P. 253-283.

27. Searle J. R. Metaphor. Metaphor and Thought. 1993. P. 83-111.

28. Gibbs R. W. The Poetics of Mind. Figurative Thought, Language and Understanding. Cambridge : Cambridge University Press, 1994. 527 p.

29. Kövecses Z. Metaphor. A practical introduction. Oxford University press, 2002. $285 \mathrm{p}$.

30. Присяжнюк Л. Ф. СВІЙ/ЧУЖИЙ в образній системі романів Г.Гріна: семантико-когнітивний аспект : дис. ... канд. філол. наук : 10.02.04. Київ, 2007. 243 с.

31. Semino E. Schema theory and the analysis of text worlds in poetry. Language and Literature. 1995. № 2. P. 79-107. 
32. Croft W., Cruse D. Cognitive Linguistics. Cambridge : Cambridge University. Press, 2004. 356 p.

33. Fauconnier G., Turner M. The Way We Think: Conceptual Blending and the Mind's Hidden Complexities. New York : Basic Books, 2002. 440 p.

34. Fauconnier G., Turner M. Mental spaces: conceptual integration networks. Cognitive linguistics: basic readings. 2006. P. 303-371.

35. Fauconnier G. Mental Spaces: Aspects of Meaning Construction in Natural Language. Cambridge: Cambridge University Press, 1994. 190 p.

36. Turner M., Fauconnier J. Conceptual integration and counterfactuals. Discourse and Cognition. Bridging the Gap. 1998. P. 285-296.

37 . Werth P. How to build a world (in a loss than six days and using only what's in your head). In New Essays on Deixis: Discourse, Narrative, Literature. 1995. P. 49-80.

38. Werth P. Text worlds: Representing conceptual space in discourse. London : Longman, 1999. 390 p.

39. Semino E. Language and world creation in poems and other texts. Longman : London and New York, 1997. 288 p.

40. Gavins J. (Re) thinking Modality: A Text-world Perspective. Journal of Literary Semantics. 2005. №. 34(2). P. 79-93.

41. Gavins J. Text World Theory. Edinburgh : Edinburgh University Press, 2007. $193 \mathrm{p}$.

42. Hidalgo Downing L. Negation, Text Worlds and Discourse: The Pragmatics of Fiction. Stanford : Ablex, 2000.291 p.

43. Stockwell P. Cognitive Poetics. An introduction. London and New York, 2002. $208 \mathrm{p}$.

44. Enkvist N. E. Discourse type, text-type and cross-cultural rhetoric. Empirical research in translation and intercultural studies. 1991. P. 5-16.

45. Lyons J. Semantics. Cambridge : Cambridge University Press, $1977.897 \mathrm{p}$.

46. Yule G. The Study of Language. Cambridge, New York : Cambridge University Press, 2006. 273 p.

47. Zubin D. A., Lynne E. H. The deictic center: A theory of deixis in narrative. Deixis in narrative: a cognitive science perspective. 1995. P. 129-155.

48. Levinson S.C. Pragmatics. Cambridge : Cambridge Univ. Press, $1983.420 \mathrm{p}$.

49. Bühler K. The deictic field of language and deictic words. Speech, place and action: Studies in deixis and related topics. 1982. - P. 9-30. 
50. Fillmore C. J. Toward a Theory of Deixis. University of Hawaii, Working Papers in Linguistics. 1971. № 3/4. P. 219-242.

51. Rauh G. Aspects of Deixis. Essays on Deixis. 1983. P. 9-60.

52. Diewald G. M. Deixis und Textsorten im Deutschen. Tübingen : Niemeyer, $1991.435 \mathrm{p}$.

53. Cook G. The discourse of advertising. London : Routledge, 1992. $272 \mathrm{p}$.

54. Кухаренко В. А. Интерпретация текста. Одесса : Латстар, 2002. 292 c.

55. Гальперин И. Р. Текст как объект лингвистического исследования. Москва : Наука, 1981. 139 с.

56. Селіванова 0. О. Сучасна лінгвістика : термінологічна енциклопедія. Полтава : Довкілля, 2006. 716 с.

57. Смущинська І. В. Суб'єктивна модальність французької прози. Київ, 2001. 255 с.

58. Бацевич Ф. С. Нариси з лінгвістичної прагматики: монографія. Львів: ПАІС, 2010. 336 с.

59. Балли Ш. Общая лингвистика и вопросы французского языка. Москва : Изд-во лит. на иностр. яз., 1955. 416 с.

60. Fowler R. Linguistics and the Novel. London : Methuen, 1977.141 p.

61. Rescher N. Topics in philosophical logic. Dordrecht: Reidel Publishing Co., 1968. 347 p.

62. Coates J. The Semantics of Modal Auxiliaries. London: Croom Helm, 1983. $259 \mathrm{p}$.

63. Hengeveld K. Layers and operators in functional grammar. Journal of linguistics, 1989. №. 25. P. 127-157.

64. Palmer F. R. Modality and the English Modals. London; New York : Longman, 1979. $196 \mathrm{p}$.

65. Simpson P. Language, Ideology and Point of View. London : Routledge, 1993. 198 p.

66. Grice H.P. Meaning. Philosophical Review. 1957. № 66. P. 377-388.

67. Nuyts J. Modality: Overview and linguistic issues. The Expression of modality. 2006. P. 1-26.

68. Смущинська I. В. Модальність французького художнього тексту: типи та засоби вираження : автореф. дис. ... д-ра філол. наук : 10.02.05. Київ, 2003. 39 с.

69. Маріна О. С. Контрастивні тропи і фігури в американській поезії модернізму: лінгвокогнітивний аспект : дис. ... канд. філол. наук : 10.02.04. Київ, 2004. 202 с. 
70. Tannen D. Framing in Discourse Framing in Discourse. New York: Oxford University Press, 1993. 263 p.

71. Rumelhart D. Schemata: The building blocks of cognition. Exploration in Language, Literature and Culture Poetics. 1980. P. 33-58.

72. Werth P. «World Enough, and Time». Deictic Space and the Interpretation of Prose. Twentieth Century Fiction: From Text to Context. 1995. P. 181-205.

73. Dijk van T.A. Text and context: Explorations in the semantics and pragmatics of discourse. London: Longman, 1977. 282 p.

74. Barsalou L. Frames, concepts, and conceptual fields. Frames, fields, and contrasts: New essays in semantic and lexical organization. 1992. P. 21-74.

75. Жаботинська С. А. Посесивна конструкція і концептуальні трансформи. Мова. Людина. Світ: Зб. наук. ст.: До 70-річчя проф. М.П. Кочергана. 2006. С. 178-192.

76. Langacker R. Concept, Image and Symbol, the Cognitive Basis of Grammar. Berlin; New York : Mouton de Gruyter, 1990. 546 p.

77. Жаботинская С. А. Концептуальный анализ языка: фреймовые сети. Мова. Науково-теоретичний часопис із мовознавства. Проблеми прикладної лінгвістики. 2004. № 9. С. 81-92.

78. Langacker R. W. Foundations of Cognitive Grammar. Theoretical Prerequisites. Stanford : Stanford University Press, 1987. 516 p.

79. Дридзе Т. М. Текстовая деятельность в структуре социальной коммуникации: Проблемы семиосоциопсихологии: монография. Москва : Наука, 1984. 232 с.

80. Приходько Г. І. Оцінка і комунікація : посіб. для студентів та аспірантів. Вінниця : Нова Книга, 2013. 168 с.

81. Austin J. L. How To Do Things With Words. Cambribge / Mass.: Harvard Univ. Press, 1962. 166 p.

82. Grice H. P. Logic and Conversation. Syntax and Semantics volume 3: Speech Acts. 1975. № 3. P. 41-58.

83. Гак В. Г. Прагматика, узус и грамматика речи. Иностранные языки в школе. 1982. № 5. С. 7-11.

84. Карасик В. И. Языковой круг: личность, концепты, дискурс: монография. Волгоград : Перемена, 2002. 477 с.

85. Безугла Л. Р. До питання розмежування прагматики, стилістики та прагмастилістики. Дискурсологія: семантика і прагматика. 2014. С. 6-10.

86. Почепцов Г. Г. Аспекты коммуникативно-прагматического анализа текста в свете теории речевого воздействия. Материалы 
VIII Всесоюзного симпозиума по психолингвистике и теории коммуникации : тез. докл. 1985. С. 121-122.

87. Heusinger S. Pragmalinguistik: Texterzeugung, Textanalyse; Stilgestaltung und Stilwirkungen in der sprachlichen Kommunikation: ein Lehr-und Übungsbuch. Frankfurt am Main : Haag und Herchen, 1995. 162 s.

88. Корольова А. В. Стратегії і тактики комунікативної поведінки учасників спілкування в ситуаціях конфлікту. Studia Linguistica. Збірник наукових праць. 2008. № 1. С. 48-53.

89. Клюев Е. В. Речевая коммуникация. Москва : ПРИОР, 1998. 320 с.

90. Бахтин М. М. Эстетика словесного творчества. Москва : Искусство, 1979. 423 с.

91. Воробьева О. П. Лингвистические аспекты адресованности художественного текста (одноязычная и межьязычная коммуникация) : дис. ... д-ра филол. Наук : 10.02.19. Москва, 1993. 382 с.

92. Колегаева И. М. Текст как единица научной и художественной коммуникации. Одесса : Изд-во ОГУ им. И.И. Мечникова, 1991. 120 с.

93. Шмид В. Нарратология. Москва : Яз. слав. культуры, 2003. 312 с.

94. Булыгина T. В.Языковая концептуализация мира (на материале русской грамматики). Москва : Шк. “Языки русской культуры", 1997. 574 с.

95. Ильин И. П. Имплицитный автор. Современное зарубежное литературоведение (страны Западной Европы и США): концепции, школы, термины: Энциклопедический справочник. 1999. С. 46-48.

96. Iser W. Der Akt des Lesens: Theorie ästhetischer Wirkung. München, 1976. 357 s.

97. Eco U. The role of the reader: explorations in the semiotics of the text. Bloomington : Indiana University Press, 1984. 273 p.

98. Палійчук А. Л. Наративний код інтимізації (на матеріалі англомовного художнього дискурсу) : дис. ... канд. філол. наук : 10.02.04. Луцьк, 2011. 253 с.

99. Genette G. Nouveau discours du récit. Paris : Seuil, 1983. 178 p.

100. Herman D. Story Logic: Problems and Possibilities of Narrative. University of Nebraska Press, 2002. 478 p.

101. Rimmon-Kenan S. Narrative Fiction: Contemporary Poetics. London, $1983.173 \mathrm{p}$.

102. Genette G. Narrative Discourse. An Essay in Method. Ithaca: Cornell University Press, 1980. 288 p.

103. Prince G. A Dictionary of Narratology. Lincoln : University of Nebraska Press, 1987. 202 p. 